\title{
Trying K-W-L Strategy on Teaching Reading Comprehension to Passive Students in Vietnam
}

\section{Tran Thi Thanh Dieu}

Faculty of English Linguistics and Literature, University of Social Sciences and Humanities, Viet Nam National University, Ho Chí Minh City, Vietnam

\section{Email address:}

thdieu2003@yahoo.com, thanhdieutt@hcmussh.edu.vn

\section{To cite this article:}

Tran Thi Thanh Dieu. Trying K-W-L Strategy on Teaching Reading Comprehension to Passive Students in Vietnam. International Journal of Language and Linguistics. Vol. 3, No. 6, 2015, pp. 481-492. doi: 10.11648/j.ij11.20150306.33

\begin{abstract}
In the project to discover the difficulties facing Vietnamese learners of English and the solution, being the Special Issue in the International Journal of Language and Linguistics, numbered 501024 (http://www.sciencepublishinggroup.com/specialissue/501024), reading comprehension is one of the difficulties to be discovered facing Vietnam learners, for which the solution discussed in this paper was analyzed to complete the project for the Special Issue 501024. Therefore, this study focuses on the importance of the Schema theory in reading comprehension. To prove the benefit of prior knowledge, K-W-L strategy was used as treatment in the experiment. The hypothesis was that the K-W-L method would help passive students improve their reading comprehension skill. The final target was trying to change students from negative attitudes to positive feeling towards reading class after the K-W-L method was used and to improve Vietnamese students' reading skill as well as catching the main idea in the reading texts in order to have successful communication in English. As a result, the research has proved the effect of the treatment. It also suggested a way to control a reading class, to create an interesting and exciting atmosphere to improve students' reading comprehension skill.
\end{abstract}

Keywords: Schema Theory, K-W-L Strategy, Reading Comprehension, Treatment, Experimental Group, Control Group

\section{Introduction}

According to Achersold and Field (1997:15), Reading is what happens when people look at text and assign meaning to the written symbols in that text [1]. One more suggestion is that reading is the interaction between the text and the reader that creates meaning. Models of reading in a first language have been created to describe this interaction between reader and text, and what happens when people read. The three main models of how reading occur are Bottom-up theory, Top-down theory and the Interactive school of theories.

Every model has its own advantage, but the question is which is the most suitable to the passive students. In other words, how to make students feel interested in reading, especially reading in a foreign language is still a vexed question. As a result, we are having a project to discover the difficulties facing Vietnamese learners of English and the solution, being the Special Issue in the International Journal of Language and Linguistics, numbered 501024 (http://www.sciencepublishinggroup.com/specialissue/50102

$4)$. Therefore, reading comprehension is one of the difficulties facing Vietnam learners, for which the solution discussed in this paper was analyzed to complete the project for the Special Issue 501024.

From Anthony, Pearson, \& Raphael's definition of reading: "Reading is the process of constructing meaning through the dynamic interaction among the reader's existing knowledge, the information suggested by the written language, and the context of reading situation (1993:284)" [2], Schema theory suggests that readers have prior knowledge about a topic before they read. This prior knowledge can be similar (and thus elaborated on) to what the reader will encounter in a new text. Alternatively, it may be in conflict with the topic or non-existent. In this case, teachers can play a vital role in seeing that the readers' knowledge about the new topic is built up so that they can successfully comprehend a new text. Prior knowledge can create interest in readers. No one can deny this, but how to relate existing knowledge to the topic they are reading. One model of reading, called the top-down model, argues that readers bring prior knowledge and experience to the text and that they continue to read as long as the text confirms their expectation. According to Dr. Renandya and Dr. 
Jacob, the simple procedure helps teachers become more responsive to the students' knowledge and interests when reading expository material, and it models for students the active thinking involved in reading information is the $K-W-L$ strategy: A teaching model that develops active reading of expository text [12]. Nobody would think of questioning the advantages of this strategy, but passive student is a vexed question. Therefore, as a proverb goes: "Seeing is believing", the researches on improving reading comprehension skill have been carried out every two years from 2005 to 2015, also for the Special Issue project 501024 in the International Journal of Language and Linguistics, to prove the advantage of this strategy with the hope to convince teachers to use this strategy in teaching reading, especially to passive students.

\section{Rationale}

\subsection{Theory and Practical Reasons}

\subsubsection{Theory Reasons (Literature Review)}

\section{(i). Discovering the Classroom Community}

David Mayo, in a research named "Discovering the classroom community" remarked that there are two forms of students cooperation that are common in EFL classes: small group (typically, four students) and pairs [21]. He had found each form good in its way; at least for task they were product-oriented. He felt the need to re-think cooperation while planning a new course that valued more students imitative in the process of learning. Learners in the new course were organized into group of four for discussion, writing and oral reporting. It also revealed that small group can be used as a way of promoting cooperation in learning process. With the ultimate aim of realizing differentiated classes in which "both what is learned and the learning environment are shaped to learner" (Tomlinson, 1999, p2), he designed a flexible collaborative learning arrangement that balances mutual support with individual initiative more dynamically than the small-group model and he became more attentive to the principle of collaboration, which stress mutuality among responsible individuals rather than mere labor-sharing. However, he didn't talk about what field can be the topic for group work.

\section{(ii). Level of Understanding}

In a research paper about comprehension testing, or can understanding be measured? Bernard Spolsky-Department of English, Bar-Han University, Israel has observed the way of assessing understanding and concluded that comprehension of a foreign-language depends not just on knowledge of the second language but also on prior knowledge of the topic or content, some studies have been concerned to look for evidence of bias. One of the most recent of such studies has been by Hale (1988), who was able to look at over 30,000 students taking TOEFL examination. Hale selected 21 different reading passages, intended to be general, and divided them according to topic into biological/physical sciences and humanities/ social science. There was evidence of statistically significant difference, so that subjects did better with passage in their field, but the practical effect was slight: had all students been rested with passages in their own field, the difference would have been 3 points (the standard deviation of test is normally about 6 . Points).

\section{(iii). Students' Attitude Towards Reading Text}

Chitra Varaprasad is a lecturer at the English Proficiency Unit at the National University of Singapore and has taught Communication Skills, English Proficiency, and Academic Skills courses. In research named "Some Classroom Strategies (Developing Critical Literacy Awareness)" remarked that the student's attitude to texts is that the "text knows best." Students tend to "passively accept what is found in reading texts simply because it is so often presented as obvious" (Wallace 1990) [28]. Secondly, teachers generally use texts as a means to impart grammatical, vocabulary, and content knowledge. They are more concerned that students comprehend these different elements in a text and therefore seldom enable students to question a text's "obvious" and "taken for granted" stance (Wallace 1990). So the term critical here implies that students do not blindly accept the "obvious" statements in a text. They need to move beyond challenging overt statements to taking an assertive stand against the text's assumptions. Teachers need to guide students to question the information content and the ideological assumptions that the writer puts forth. This paper has tried to describe critical reading briefly and explain what it entails as well as discuss strategies that can develop critical reading ability among post-secondary students. These were presented in the context of the three stages of reading. The emphasis was on questioning, analysing, and evaluating. The purpose of these stages is to get students to examine texts in more critical, reflective ways, to encourage them to take assertive positions against texts, and to feel that they have options in the way they choose to read texts Some ideas on teaching implications have been provided and suggestions have also been made regarding the kinds of materials that can be used in the classroom. The change in teaching suggested by a critical reading approach will foster better readers by helping students to focus on the ideology and assumptions behind the author's words. This places the author of the text in a sharper focus. This fosters a more meaningful "dialogue" between the student reader and the unknown writer of the text. The critical reading approach can be used with a wide variety of genres, but texts such as advertisements, which have a clear agenda, are a good place to start. All teachers work within certain constraints in the classroom, but the need for developing critical reading strategies among our students cannot be ignored. The approach described when dealing with reading texts in language can also be extended to content- subject classrooms.

\section{(iv). Eliciting Student-Talk}

The research named "Eliciting Student-Talk" by Michael E. Rudder revealed that traditionally, the teacher was viewed as an organizer of classroom activities; a controller over the implementation of these activities; and an evaluator of students' performances of the activities [29]. This dominant 
role was based on the premise that the teacher was the "expert" who would impart his or her knowledge or "expertise" to the unknowing student, who in turn would be assessed by evaluation instruments intended to measure the amount of transferred "expertise".

Nowadays, students play a much more active role in the learning process. No longer passive recipients, they are contributing to the planning and implementation of what transpires in the classroom; continually adopting and adapting strategies to accomplish immediate as well as long-term goals; and acquiring and developing critical thinking and cooperative learning skills. This emphasis in language teaching and learning is on the communicative nature of language. It is the content of the message that takes preeminence over accuracy of form. In short, the essence is language for communication and self-expression.

Adrian Doff (1988) discusses the value of this type of elicitation by making the following points. First, it helps to focus the students' attention and make them think. Second, it helps students make the connection between what they already know and what they are about to learn. Third, it helps the teacher assess what the students already know, thereby making it easier to adapt the presentation to an appropriate level. I would add that the inclusion of eliciting in the presentation stage adds variety to an otherwise teacher-dominated activity and enhances student motivation.

\section{(v). The Importance of Prior Knowledge}

According to Anderson's research, prior knowledge is extremely important in influencing how we interpret what we read and what we learn from reading [1]. To read well, we must access the knowledge we already have about the topic or make it available appropriately so that comprehension can occur (Anderson and Pichert, 1987; Bransford, 1983). However, they haven't had a detailed analysis of the effect of the combination of the three steps: K (What we know), W (What we want to find out, and L (What we learned and still need to learn) on encouraging and guiding Passive students to participate in the lesson to improve their reading skill as well as speaking, listening and writing skill: the four main skill for language acquisition.

\subsubsection{Practical Reasons}

\section{(i). The Importance of Prior Knowledge}

According to Anderson's research, prior knowledge is extremely important in influencing how we interpret what we read and what we learn from reading. To read well, we must access the knowledge we have already had about the topic or make it appropriately available so that comprehension can occur (Anderson and Pichert, 1987; Bransford,1983) [20]. However, they have not had a detailed analysis of the effect of the combination of the three steps: K (What we know), W (What we want to find out, and L (What we learned and still need to learn) on encouraging and guiding passive students to participate in the lesson to improve their reading skill as well as speaking, listening and writing skill: the four main skills for language acquisition.

\section{(ii). Boring Atmosphere}

Second, in Vietnam, "Dr. Anaesthetist" the name usually given to teachers who teach reading can describe the atmosphere of a reading class since the teachers' method is so boring or the students are too passive; we can not have the accurate answer. However, the name "Dr Anesthetist" just given to the teachers can be understood as accusing the teachers. What they teach only make the students "feel sleepy", even "losing consciousness" with the meaning that students have a deep sleep that are very difficult to be waken up and the teacher's ability of making students sleepy is at the highest level; not "Bachelor", not "Master" but as high as the level of "Doctor", the highest level in the academic process. This satire can make us feel funny, but we, as teachers, can we laugh impartially? Specially, the lack of interest from students at the starting points in a reading class may lead to the whole boring atmosphere Therefore, how to make the reading class become more exciting appears to be the purpose for this paper.

\section{(iii). Finding out Students' Problem}

Moreover, no one can deny that the exciting atmosphere can not be created by only a teacher. If the teacher asks lots of question without reply, it will become a mono rhyme. In addition, the reply from students are not enough; therefore, what more important is their questions. Since there is only one teacher in class, he can not think of all students' problems. As a result, students' questions become a step for further and detailed explanation by the teacher.

However, the most important question is which causes the silence from students: The survey conducted in this research reveals that Vietnamese dare not talk so much in class to show their respect to the teacher. In addition, before finishing the lessons, the teacher usually asks students: Are there any questions? The answer in chorus is "No". However, the teacher dare not feel satisfied with the "complete understanding" from students because he clearly knows that the students have no question because they do not have anything unclear or they do not know how to ask, they do not know what to ask, and they do not know anything to base on to think further, as well. In short, the students can not relate the topic to their background knowledge to have deeper thinking for successful comprehension.

With these problems, the time has come when the solution for reading class should be found out, to change from "sleepy" to "interesting" and "exciting" atmossphere.

\subsection{Research Questions}

Based on the rationales presented above, the following research questions are formed:

1. Does KWL method help passive students improve their Reading comprehension skill?

2. What is the students' thinking of the KWL method?

3. Are there any changes in students' attitudes towards Reading class after the KWL method is used? 


\section{Methodology}

\subsection{Variables - Anything That Can Vary in a Study}

Research is largely the study of what happens when variables are systematically manipulated in planned combinations [23]. In my research, Variables play the following roles:

1. Dependent variable: The experimental group: The participants - The students who are taught by using the KWL strategy - the treatment. This is the variable of primary focus, the variable that is measured and studied to determine if other variables have an effect on it.

2. Independent variable (manipulated variable): The KWL strategy, which have been selected in order to study its effect on the dependent variable.

These are two variables which can be used to answer the question "what is the effect of the KWL strategy on passive students?". Moreover, the relationship between these independent and dependent variables is central to the study.

3. Control variable: To find out and prove the effect of the KWL strategy, one of the best way is to compare the score of the groups receiving the KWL strategy with the other groups that did not receive the KWL strategy (the treatment), but received the Ordinary strategy. The second groups is the control group - the control variable which are eliminated from the study, held constant, or otherwise kept from interesting with the study of the central relationship between the independent and dependent variables.

\subsection{Participants}

The research was carried out with 90 Vietnamese students who were from 3 kinds of source - Pre intermediate (30 participants for every source), called "population":

1. Students of Non-English Department in University of Social Sciences \& Humanities.

2. Learners of Foreign language Center in University of Social Sciences \& Humanities.

3. Students of Non-English Department in Van Hien University.

Variety kinds of students source were chosen in order to ensure the reliability of the effect of a strategy (KWL strategy). However, the population is clearly identified with the salient characteristics, called strata, which ensured that the population must be at the same passive level, and chosen by checking as follow:

3 classes were divided from 3 sources above. In every class, all of the students must do 2 reading tests (Multiple-choice and Story - frame (Cloze Test)). 30 students who have the same lowest mean (of the 2 reading test) are chosen. In addition, the sampling techniques used is Stratified random sampling.

30 students chosen in every class are randomly divided into 2 groups on the basis of a table of random number: 15 participants for control group (which is used to try the ordinary strategy to teach reading) and 15 participants for experimental group (which is used to try the KWL strategy to teach reading), called "sample".

\subsection{Materials}

- Classroom documents: Text book: The Texts for teaching Reading, homework assignment, worksheets, class materials. Many of these provide primarily action data since they show what students have done. They are very valuable in helping teachers address problems that involve individual students and their progress in what they are learning. This kind of materials also provides a way of checking to see whether or not teachers have used an effective method, the strength and weakness of the treatment: teaching by using KWL strategy.

- Lesson plan: for ordinary strategy and for KWL strategy, in order to describe what teacher plan to do in a class and what they actually do. The more detailed the lesson plan is the easier for teachers to recognize and solve the problem. Moreover, the Lesson plan also involves reflection-on-action after the lesson has occurred: A lesson planning reflection sheet which helps the teachers not only examine how they have handled a particular aspect of the lesson they have just taught but measure the result of the experiment as an instrument.

Table 1. Lesson plan for Ordinary strategy.

\begin{tabular}{|c|c|c|}
\hline Step & Time & Activities \\
\hline \multicolumn{3}{|c|}{ Pre-Activity } \\
\hline 1 & $10 \mathrm{~m}$ & $\begin{array}{l}\text { Provide students some key words and some } \\
\text { new grammar points. }\end{array}$ \\
\hline 2 & $10 \mathrm{~m}$ & $\begin{array}{l}\text { - Ask students to make some example using the } \\
\text { new grammar points. }\end{array}$ \\
\hline \multicolumn{3}{|c|}{ Main-Activity } \\
\hline 1 & $25 \mathrm{~m}$ & $\begin{array}{l}\text { Students (work in pair) skim to find the } \\
\text { structure of the text (number of paragraphs or } \\
\text { parts) and the main idea of every paragraph or } \\
\text { part by looking for the topic sentence in every } \\
\text { paragraph or part (I guide them that the topic } \\
\text { sentence is usually at the beginning of the } \\
\text { paragraph/part (deductive procedure), or at the } \\
\text { end of the paragraph/part (inductive } \\
\text { procedure), or at the middle } \\
\text { (inductive-deductive procedure). } \\
\text { - Let students do the word-matching exercise }\end{array}$ \\
\hline 2 & 15 & $\begin{array}{l}\text { (match the words in column A with their } \\
\text { definition in column B) or Gap-filling } \\
\text { exercises. }\end{array}$ \\
\hline 3 & 20 & $\begin{array}{l}\text { - Let students answer the comprehension-check } \\
\text { questions. }\end{array}$ \\
\hline \multicolumn{3}{|c|}{ Post-Activity } \\
\hline 1 & 5 & $\begin{array}{l}\text { - Summarize the grammar points that have just } \\
\text { been taught. }\end{array}$ \\
\hline 1 & 5 & - Asking students if they have any problem. \\
\hline
\end{tabular}


Table 2. Lesson plan for KWL strategy.

\begin{tabular}{|c|c|c|}
\hline Step & Time & Activities \\
\hline \multicolumn{3}{|c|}{ Pre-Activity: Train students to collect their schema and find out their lack of info } \\
\hline \multirow{4}{*}{1} & & $\begin{array}{l}\text { K-W step: Acitvate students' schema relating to the topic of the text and find out what they don't know and want to know: Work in group. } \\
\text { - Use } 2 \text { steps of } 2 \text { levels to access prior knowledge in step }(\mathrm{K}) \text { : } \\
\text { - The first is the straightforward brainstorming of what the group knows about the topic for reading: to select a key concept for the } \\
\text { brainstorming that is specific enough to generate the kind of information that will be pertinent to the reading. } \\
\text { - The teacher's role is to record whatever the students volunteer about the topic on the board or an overhead projector. } \\
\text { - The second part is eliciting what is already known. } \\
\text { By: } \\
\text { OR Make some questions to relate students to the content of the text then students discuss the answer of the questions. } \\
\text { OR }\end{array}$ \\
\hline & $10 \mathrm{~min}$ & $\begin{array}{l}\text { OR Modeling } 1 \text { or } 2 \text { examples from the information that have already generated, then students begin to think of categories that can be } \\
\text { added to the list. }\end{array}$ \\
\hline & & $\begin{array}{l}\text { OR } \\
\text { In order to help }\end{array}$ \\
\hline & & $\begin{array}{l}\text { - Students find out what they don't know and what they want to know. } \\
\text { - If not all students agree on the same pieces of information, some pieces of information is conflicting, some of the categories have had } \\
\text { no particular information provided. }\end{array}$ \\
\hline 2 & 5 & $\begin{array}{l}\text { Highlight their disagreements and gaps in information and help the students raise questions that focus their attention and energize } \\
\text { their reading. }\end{array}$ \\
\hline 3 & 5 & Preview the article (Text) to discern the match between students' expectations and the actual construction of the article. \\
\hline 4 & 5 & Note difficult or unclear sections for students \\
\hline \multicolumn{3}{|c|}{ Main-Activity: } \\
\hline 1 & $10 \mathrm{~min}$ & $\begin{array}{l}\text { - Provide students some key words and some new grammar points to help them read the text to find out the answer for their questions } \\
\text { then ask students to make some example using the new grammar points. } \\
\text { - Students (work in groups) skim to find the structure of the text(number of paragraphs or parts) and the main idea of every paragraph or } \\
\text { part (Work in groups). }\end{array}$ \\
\hline 2 & 10 & - Let students do the word-matching exercise (match the words in column A with their definition in column B) or Gap-filling exercises. \\
\hline 3 & 20 & $\begin{array}{l}\text { Work in groups depending on the number of the parts in the text: After reading carefully follow the given questions, students in the } \\
\text { same group on the same piece of paper as much as possible what they remember about the text - part by part, relate them to their } \\
\text { question and find out what are not related to their questions: the new things that are higher than their background knowledge. Then } \\
\text { every group report to the whole class their summary or answer the given comprehension questions. }\end{array}$ \\
\hline \multicolumn{3}{|c|}{ Post-Activity } \\
\hline & & - L Step: what I learned \\
\hline 1 & 20 & $\begin{array}{l}\text {-The whole text summary and report } \\
\text { Students summarize the whole text (principle 4), then report to the class briefly. The class listen and a volunteer student report again more } \\
\text { briefly in writing (not pay much attention to the grammatical correctness). After that the teacher corrects to make the more perfect } \\
\text { summary. }\end{array}$ \\
\hline 2 & 5 & -Adding more information: \\
\hline 2 & 5 & $\begin{array}{l}\text {-Further Reading: } \\
\text { Having them check their questions to determine if the article dealt with their concerns. If not, suggest further reading to fulfill their desires } \\
\text { to know. Give students some more names of book relating to the text for further reading \& ask them to summarize briefly a book they like } \\
\text { best. }\end{array}$ \\
\hline
\end{tabular}

\subsection{Pilot Study}

The pilot study of the experiment to passive students and questionnaire (to both teachers and students) was carried out with teachers and students at the researcher's own department prior o the actual experiment. Teachers and students who participated in the pilot study were also English teachers and second year students at non-English department and Intermediate level learners at the Foreign Language Center respectively.

The experiment was tried out on 90 students from the 3 sources:

1. Non-English Department in University of Social Sciences \& Humanities.
2. Foreign language Center in University of Social Sciences \& Humanities.

3. Non-English Department in Van Hien University.

\subsection{Procedure \& Research Schedule}

After the pilot study had been conducted and all the revision had been made, the researcher approached the Heads of Departments at University of Social Sciences \& Humanities and Van Hien University with Teachers and students at the researcher's institution to obtain permission for the research. When permission was granted, Researcher discussed with colleagues for good advice to prepare:

- The test for choosing participants (Population)

- The lesson plans 
- The Test for evaluation the result of trial teaching

- Questionnaire

Working with students to carry out the examination for choosing participants (population) at the examination room and randomly choose the sample students at classrooms were taken place right after that. The best time for research to be carried out is around the beginning of the semester (around September for the $1^{\text {st }}$ semester and February for the $2^{\text {nd }}$ semester) because the whole semester is acceptable shortest term for the trial teaching.

After finishing the trial teaching program with some teacher colleagues invited for class observation (using the KWL strategy and ordinary strategy), the examination for evaluating the result of trial teaching was carried out in the Examination-Room, then the questionnaire was sent to the students at Department Heads and classroom to collect the students' thinking of the KWL method and find out the changes in students' attitudes towards reading class after the KWL method was used and teacher colleagues' comments on classroom atmosphere as well as students activities. At the end, videotape was watched at Video-room to have self-observation and the completed questionnaire was collected at Department Heads and classroom for Data Analysis in Researcher's institution. To ensure the smooth flow of the research, the following timetable was proposed:

Table 3. Reaearch Schedule.

\begin{tabular}{|c|c|c|}
\hline Time & What to do (Action) (Step) & Subject matter \\
\hline Week 1 & Conduct the pilot study & Teachers and students at the researcher's institution \\
\hline Week $2+3$ & $\begin{array}{l}\text { Prepare } \\
\text { - } \quad \text { The test for choosing participants (Population) } \\
\text { - } \quad \text { The lesson plans } \\
\text { - } \quad \text { The test for evaluation the result of trial teaching } \\
\text { - Questionnaire }\end{array}$ & Researcher and colleagues discussions \\
\hline Week 4 & - Obtain permission for the research & Department Heads of 2 institutions (USSH and VHU) \\
\hline Week $5+6$ & $\begin{array}{l}\text { - Carry out the examination for choosing participants } \\
\text { - Random choosing the sample }\end{array}$ & $\begin{array}{l}\text { Students at the examination - room } \\
\text { Students at classrooms }\end{array}$ \\
\hline $\begin{array}{l}3 \text { months } \\
\text { (Week7-18) }\end{array}$ & $\begin{array}{l}\text { - Carry out the trial teaching program } \\
\text { (using the KWL strategy and ordinary tartly) }\end{array}$ & Students and some teacher colleagues at class rooms \\
\hline Week 19 & - Carry out the examination for evaluation the result of trial teaching & Students at the examination - room \\
\hline Week 20 & - Send the questionnaire to students & Classroom \\
\hline Week $21+22$ & $\begin{array}{l}\text { - Collect the completed questionnaire } \\
\text { Watch videotape }\end{array}$ & $\begin{array}{l}\text { Classroom } \\
\text { Video-room }\end{array}$ \\
\hline
\end{tabular}

\subsection{Design}

\subsubsection{Experimental Research}

Experimenta research was used to check some kinds of cause and effect relationship, the only thing to do, the research that isolates the two variables, get data, and see how data was compared. Experiments, or other forms of Quantitative research, are useful when working with numerically measurable data under controlled conditions. It provides excellent techniques for getting very specific information, because when finding out the effect of the KWL strategy, we have to work with numerically measurable data, the score of testing from the two kinds of population: control groups and experimental groups. However, to people, they often act in complex and unexpected ways that are beyond the parameters of experimental hypothesis. Experimental exactitude, which might require controlled conditions, tends to make people behave self-consciously or unnaturally.

Treatment: Teaching using KWL strategy.

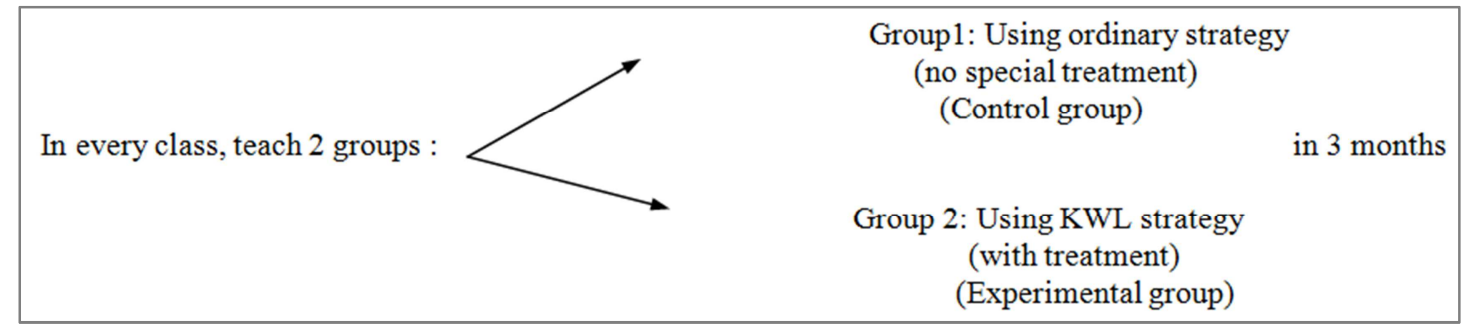

Figure 1. The two teaching trategies used in the research

Using the 2 kind of Lesson plan: Lesson plan for ordinary strategy and Lesson plan for KWL strategy to teach 2 groups: Control and Experimental group in every source of participants:

1. Students of Non-English Department in University of Social Sciences \& Humanities.
2. Learners of Foreign language Center in University of Social Sciences \& Humanities.

3. Students of Faculty of English Linguistics and Literatures in University of Social Sciences \& Humanities.

Try variety kinds of student source in order to ensure the 
reliability of the effect of a strategy (KWL strategy).

- Before using the KWL strategy, explained clearly what the KWL strategy is and how to use it. Show students that KWL (a thinking-reading process) is the procedure that can be used with nonfiction selections at any grade level and in any content learning situation and can help learners to access the knowledge they already have about the topic or make it available appropriately so that comprehension can occur: the first step: $K$ : What they know and then discuss to find out what they want to know: $W$ and last, after studying the text, they have to summarize what they learned and approach further to what they need to learn more (extra-knowledge): L. For the first two steps of the process, the teacher and the students engaged in oral discussion followed by students' personal response on their worksheets.

- The first step: K: There are 2 levels of accessing prior knowledge in the first step $(\mathrm{K})$ :

- The first is the straightforward brainstorming of what the group knows about the topic for reading. During this step the teacher's role is to record whatever the students volunteer about the topic on the board or an overhead projector: the critical component here is to select a key concept for the brainstorming that is specific enough to generate the kind of information that will be pertinent to the reading. The brainstorming that precedes reading needs to have its goal the activation of whatever knowledge or structures the readers have to help them interpret what they read.

- The second part of the brainstorming (or eliciting what is already known) that is useful to students in reading involves them in thinking of the more general categories of information likely to be encountered when they read.

- The second step W: (what they want to find out) is the time for students to think about what they already know about the topic and the general categories of information that should be anticipated, questions emerge. Not all students agree on the same pieces of information, some pieces of information is conflicting, some of the categories have had no particular information provided. All this reading activity develops the students' own reasons for reading - reading to find answer to question that will increase their reservoir of knowledge on this topic. The teacher's role in this stage is central: highlight their disagreements and gaps in information and help the students raise questions that focus their attention and energize their reading. However, does it has effect on passive students, the one who is so accustomed to the silence in classroom? The majority of step $\mathrm{W}$ is done as a group activity.

- In the third step L: students can either fill out the "what I learned" section as they read or do so immediately following the completion of the article; the discussion follows the individual responses. After completing the article, direct the students to write down what they learned from reading. Having them check their questions to determine if the article dealts with their concerns. If not, suggest further reading to fulfill their desires to know. In this way, teachers are setting the clear priority of students' personal desire to learn over simply talking in what the author has chosen to include.

- During every lesson, give students some kinds of classroom documents such as: homework assignments or worksheet to address problems and check if the methods are effective or not. In addition, to get the real scene to see the atmosphere of the classes using ordinary strategy and classes using KWL in order to find out if there was the decrease of the passive of students when trying KWL, videotape was used, in some groups, with the permission from students but without announcing the time they will be videotaped to reduce the unnatural behavior. Moreover, with other groups, some teacher colleagues were invited to observe students' behavior, then they completed the questionnaires or writing report of what they had seen with some comments that became one of the data for making conclusion of the KWL strategy's effect.

- After every lesson, completed the lesson planning reflection sheet used as a diary for measuring the result of the teaching methods.

\subsubsection{Survey Research}

- Using the survey research with the function of (1). Opinion survey to uncover the opinion and attitudes of the participant about specific issues (KWL strategy and their effect). Questions were developed to find out what a group of students think about the goal or objectives of a particular language program (teaching using and not using KWL strategy) as well as about its tests, materials, teaching, administration... (2). Judgment survey to obtain the view of participants (only samples). Students were asked to judge the effectiveness of a language program's objectives and materials in terms of how useful or difficult they are, how necessary to future language use especially to passive students with the purpose of encouraging them to be more active in improving reading comprehension skill, as well as how they were to learn. Students were simply providing their judgment.

- Questionnaire (self-administered and group administered questionnaire), to collect the students' thinking of the KWL method and find out the changes in students' attitudes towards reading class after the KWL method was used. This type of survey is so efficient for gathering information on a large scale and also questionnaires to collect colleagues' opinions after observing the class.

- Self-administered: used questionnaire for this class and Group administered questionnaire: used for the other classes.

- Self - administered Questionnaire used by mailing out and filled out by participants in their own home (i.e., 
they are self - administered) and then returned by mail to make sure that they were not influenced by any factors such as teacher or classmate attention.

- Group administered questionnaire which is administered to participants while they are in class or at meeting. This type can solve the problem caused by the Self - administered Questionnaire: They often have very low return rate and they must be completely self explanatory because further clarification is not possible. Moreover, by using this type, the students were captive audiences and felt obliged to fill out the questionnaire (giving a high return rate), as well as teacher could be present to explain any ambiguities as the arise and knew exactly what conditions existed when questionnaires were filled out.

- Steps in Survey project

1. Stating the construct.

2. Specifying survey objectives and research question:

- Specifying survey objective: to collect the students' attitudes towards the KWL method and find out the changes in students' thinking of reading class after the KWL method was used.

- Brainstorming items.

- Research question: What are the students' attitudes towards the KWL method and Are there any changes in students' thinking of Reading class after the KWL method was used.

3. Selecting question format.

4. Selecting statistic analysis.

5. Writing survey questions.

6. Asking panel of expert.

7. Asking students to review the items.

\subsection{Instrument Used to Collect Data of the Experiment}

\subsubsection{A Lesson Planning Reflection Sheet}

This sheet can be involved in the Lesson plan with the purpose of reflection-on-action after the lesson has occurred to examine the particular aspect of the lesson, which has just been taught, has been handled. This lesson planning reflection sheets were completed after very lesson to evaluate how the transitions between activities were handled.

\subsubsection{Two Tests}

Two tests were used to test for all the population, the students in control groups and the students in experimental groups. There are 3 control groups and 3 experimental groups from the 3 different sources with the purpose of enlarging the scope of the population to increase the reliability of the research result. So there are 3 multiple choice tests and 3 story-frames (cloze tests). From every level, the mean of the two tests (multiple choice Test \& story-frame) was used to compare between the control and experimental group with the hope that the 3 comparisons from the 3 level (of the 3 sources: 1. Students of Non-English Department in University of Social Sciences \& Humanities. 2. Learners of Foreign language Center in University of Social Sciences \& Humanities. 3. Students of Non-English Department in Van
Hien University) were nearly the same that the mean of the students in the experimental groups were higher than the mean of the students in the control groups. In addition, to make sure of the validity, the tests were marked by some more colleagues.

- Multiple-choice was used because it was objective and reliable as well as easy to score and easy to administer to large populations. It also helped focus on specific language terms or sub skills and enable a tester to include a much wider sample of grammar, vocabulary and phonology, easy to check many skills of the general knowledge that was very useful for comprehension.

- Story-frame (Cloze Test) is also very suitable to check reading comprehension skill. It not only force students to understand the text they are reading but also have them predict what relates to the text or what are going to happen in the text to fill the blank. No one can deny that guessing has much good influence in reading or listening comprehension. To have a successful guessing, students have to relate the text to their background knowledge, because background knowledge is one of the foundations for guessing. This forces students to use the strategy we want to train them "KWL". And if they can apply this procedure, they can improve their comprehension skill, the very helpful way to prove the effect of the KWL strategy, to show the success of the experimental groups in comparing to the control group without treatment.

In other words, the way to have conclusion is to compare the result of the mean (the average score of the two Post-tests, which are completely different from the test given to the students at the enter-step of the experiment to find out the passive students (the population) between the control groups and the experimental groups. The occasion that the mean of the experimental group is higher than the mean of the control group is the evidence to prove the effect of the KWL strategy.

\subsubsection{Videotape}

To observe the atmosphere of the control and the experimental group, videotape was used with the students' permission. However, the time they were videotaped was not announced with the hope that their activities were natural to show their real feeling.

\subsubsection{Colleagues' Observation and Criticizing (Just in Some Control Groups and Experimental Group to Let Some Other Groups Act Naturally Without Other Surveys)}

Ask some colleagues to attend the class to observe, then some of them reported what they observed and some of them filled the questionnaire or checked against the class observation checklist.

\subsubsection{Filled Questionnaire for Survey Research}

Filled Questionnaire was used to find out the students' thinking of the KWL and if there was any change in their attitude towards reading class. 
Table 4. The summary of the research.

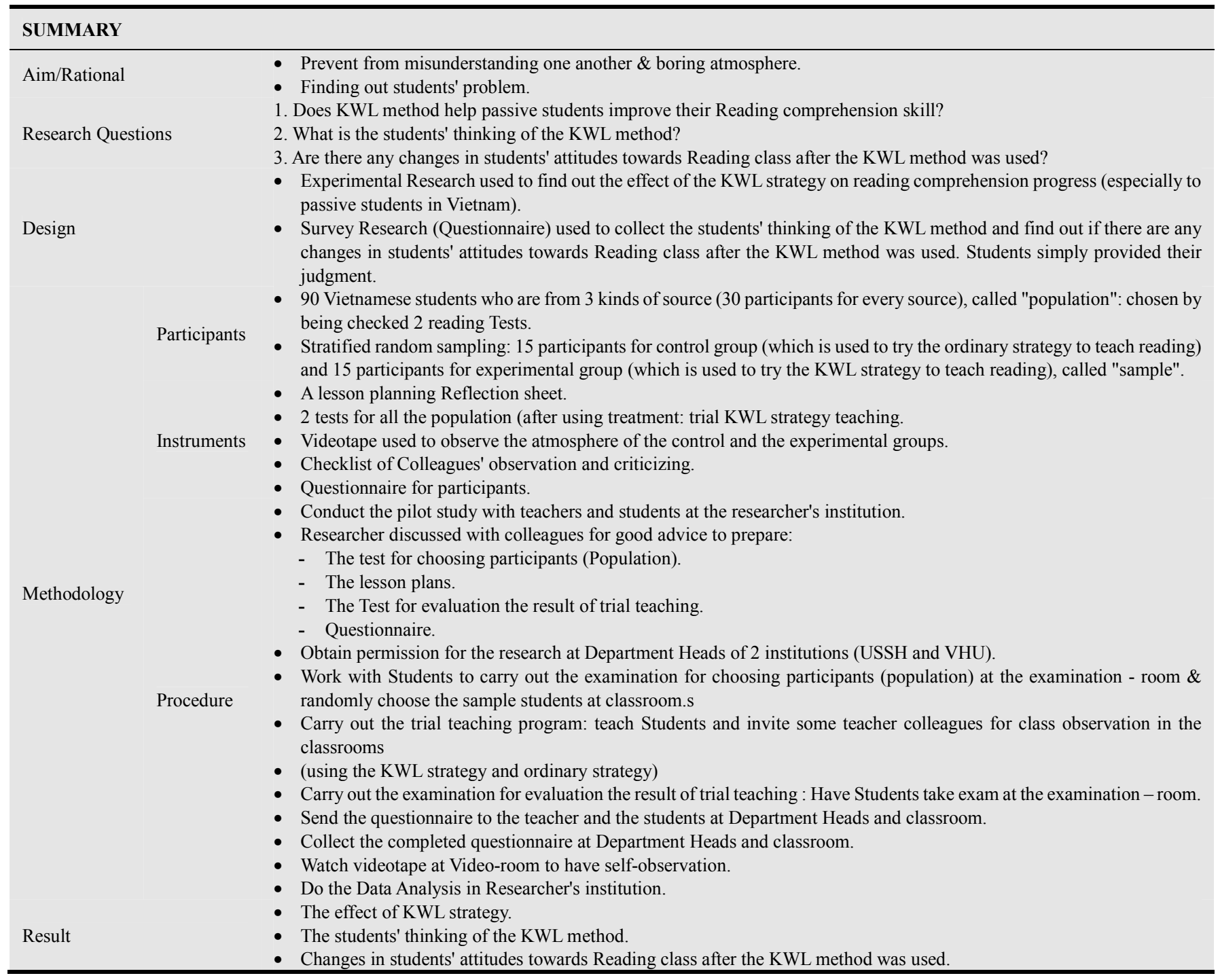

\section{Data Analysis and Findings}

\subsection{Data Analysis}

Data will be analyzed by using Microsoft Excel to analyze the average point of the 2 Tests (muliple choice \& cloze Test of 2 groups in every of the three classes for illustration.

Table 5. The score of the three Participant sources.

\begin{tabular}{lllllll}
\hline \multicolumn{2}{l}{ THE SCORE OF THREE SOURCES OF PARTICIPANTS } \\
\hline \multirow{2}{*}{ No of Ss } & Class1 & \multicolumn{3}{l}{ Class2 } & Class3 \\
\cline { 2 - 7 } & Experimental group & Control group & Experimental group & Control group & Experimental group & Control group \\
\hline 1 & 75 & 30 & 60 & 60 & 75 & 40 \\
2 & 70 & 45 & 70 & 30 & 80 & 40 \\
3 & 65 & 65 & 50 & 65 & 50 \\
4 & 60 & 50 & 70 & 50 & 70 & 45 \\
5 & 70 & 70 & 80 & 20 & 70 & 60 \\
6 & 80 & 35 & 75 & 45 & 70 & 45 \\
7 & 75 & 30 & 65 & 60 & 85 & 45 \\
8 & 85 & 30 & & & 40 \\
\hline
\end{tabular}




\begin{tabular}{lllllll}
\hline \multicolumn{2}{l}{ THE SCORE OF THREE SOURCES OF PARTICIPANTS } \\
\hline \multirow{2}{*}{ No of Ss } & Class1 & \multicolumn{7}{l}{ Class2 } & Class3 \\
\cline { 2 - 7 } & Experimental group & Control group & Experimental group & Control group & Experimental group & Control group \\
\hline 9 & 70 & 40 & 65 & 40 & 70 & 40 \\
10 & 80 & 45 & 80 & 35 & 60 & 35 \\
11 & 80 & 30 & 80 & 50 & 80 & 40 \\
12 & 70 & 45 & 80 & 45 & 70 & 45 \\
13 & 85 & 35 & 60 & 55 & 85 & 30 \\
14 & 60 & 25 & 80 & 45 & 70 & 55 \\
15 & 75 & 40 & & & 85 & 45 \\
\hline
\end{tabular}

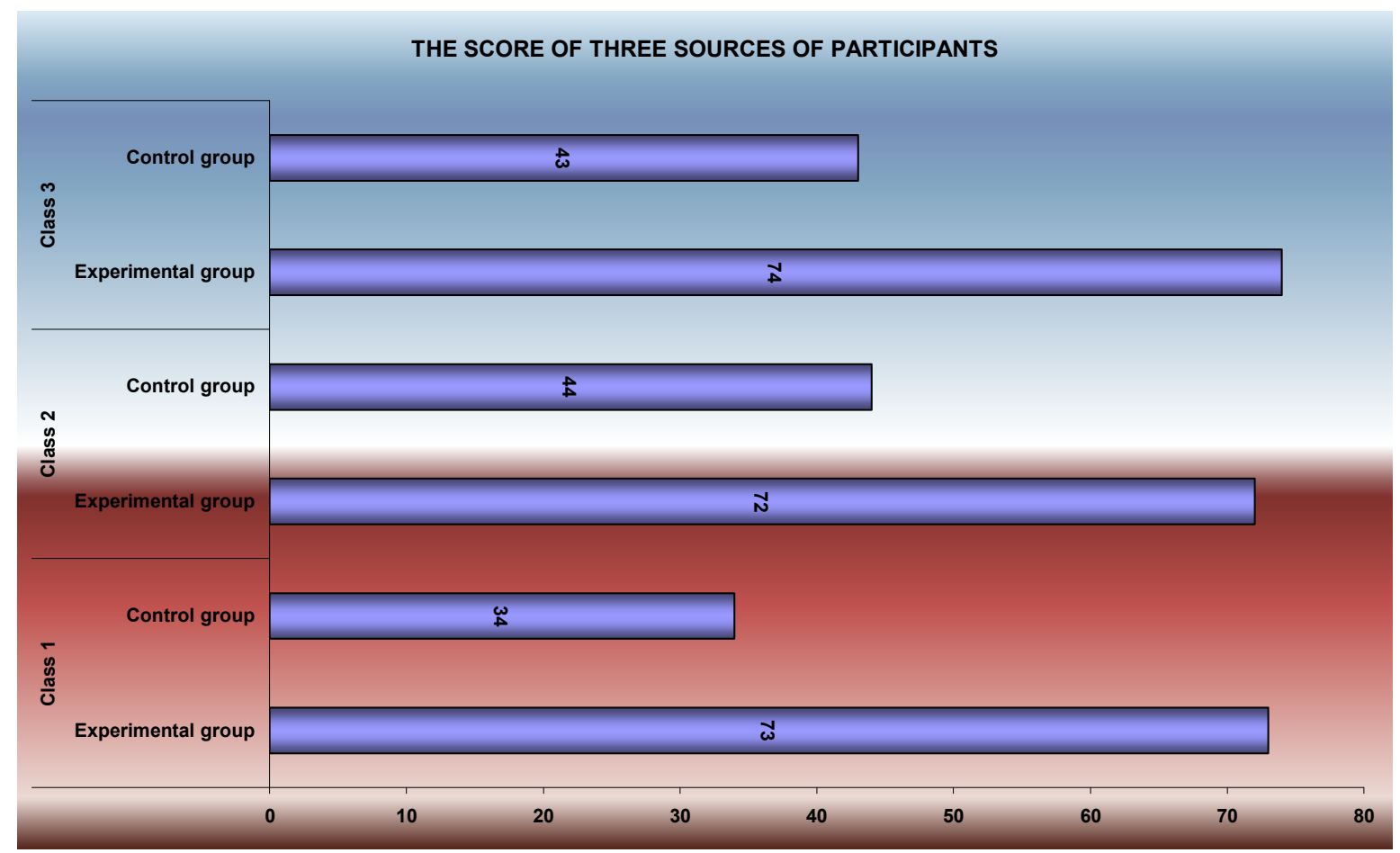

Figure 2. Score mean of the three classes.

\subsection{Findings}

\subsubsection{The Effect of KWL Strategy}

The second step W: (what they want to find out) is the time for students to think about what they already know about the topic and the general categories of information that should be anticipated, questions emerge. This step can help students improve their ability of making question, a way to participate.

KWL (a thinking-reading process) is the procedure that can be sued with nonfiction selections at any grade level and in any content learning situation and can help learners to access the knowledge they already have about the topic or make it available appropriately so that comprehension can occur.

All this reading activity developed the students' own reasons for reading - reading to find answer to question that will increase their reservoir of knowledge on this topic.

With the discussion, students seemed to be more active and interested in the lesson. Group activity in the KWL strategy gave students natural atmosphere, free from the teacher-watching pressure; therefore, step by step the passive students show their self-confidence.

Having to find out what still need to learn provided students purpose for further studying, make them feel enjoyable of reading, the main reason for activeness during the reading lessons.

This is one of the most suitable to the passive students. In other words, this strategy made students feel interested in reading, especially reading in a foreign language because this is one of the best way to activate schema, being suitable to a current perspective on reading comprehension: the reading process is an interaction between a reader's prior knowledge and the information encoded in the text. The interactive model has recently been studied under the rubric of schema theory. This theoretical framework emphasizes that the reader is an active participant who can contribute to the construction of meaning. When reading, students interpret the text in light of their previous knowledge and simultaneously modify their original schemata as new information is learned.

\subsubsection{Students' Thinking of KWL \& Students' Attitude Towards Reading Class}

Although students found some difficulties in doing the three steps K-W-L such as Personal response, Relating the prior knowledge to what is being read, Relating the prior knowledge 
to what is being read.... (in K step) and Discussion Raising question, Developing personal commitment... (in W step) as well as Writing down what they learned from reading, Judging the kinds of variation existing in different texts, Pursue their own questions for knowledge.... (in L step), they showed their interest in this strategy and as a result, their attitude towards reading class had some changes. Maybe Reading class wil be not the time of sleeping anymore. The teachers who teach reading can forget the name ""Dr. Anaesthetist" and the most important result can be gained is the usefulness of the knowledge provided to students from the interst in reading. This is the great succuess since the useful people with enough knowledge can raise the country to a higher position in the world.

\section{Closing Remarks (Reflection)}

\subsection{Strength}

- Researches on trying KWL strategy have been carried out every two years from 2005 to 2015 to ensure the validity of the result.

- Self- administered Questionnaire used to by mailing out and filled out by participants in their own home (i.e., they are self-administered) and then returned by mail to make sure that they are not influenced by any factors such as teacher or classmate attention.

- By using Group-administered Questionnaire, the students can be captive audience and feel obliged to fill out the questionnaire (giving a high return rate), as well as teachers can be present to explain any ambiguities as they arise and know exactly what conditions existed when questionnaires were filled out.

- Validity: (internal and external validity)

- To prevent from anything that happen to the subject, other intended treatment, only one strategy was used. No history, so one of the internal validity was gained.

- There is no "testing effect" (practice reflect) on the result of the experiment because different tests were used for pre-test and post-test. The first test used was just the test for choosing population. The result of the experiment was evaluated by only one set of test (multiple-choice and cloze test) that was done only one time and the conclusion gained from the comparison between the control and the experimental group that were at the same level before doing experiment.

- The research also gained the interaction of selection biases because the treatment was tried on the three sources of population. It can prevent from the fact that a particular population may cause the treatment to be effective where it would not be in another population.

- The measuring instruments were designed with care without ambiguity and large scope concepts.

- The questionnaire and test content was clear, and so were the rubic or instructions. This may lead to reliable data, because the drafts of the instruments had been checked by colleagues and the questions in the questionnaire were answered correctly.

\subsection{Weak Points Existed and May Happen}

- Researcher expectancy: Because of strongly belief in the effect of the KWL strategy, teacher could be not equal when giving mark. To prevent from this, some colleagues were asked to re-score and compare the two results.

- Intervening variable appeared to have effect on the result, that may lead to the situation that any differences discovered in the score of method A (without using KWL strategy) and method B (using KWL strategy) were caused by an unanticipated intervening variable rather than the method themselves. For instance, the teacher of the experimental group was a better teacher than the teacher of the control group. Therefore, to prevent from this case, only one teacher taught both kinds of participants: control group and experimental group. However, this case of intervening variable sometimes can appear: teacher's feeling due to teacher's admiration of the KWL strategy, teacher might do the better job with all effort to the experimental group. Recognizing the problem, teacher must remind herself not to make this mistake. However, it can be appear unconsciously during the lesson when teacher completely concentrates on her lecture.

- Problem that might appear when using Self-administered used questionnaire:

1. They often have very low return rate.

2. They must be completely self-explanatory because further clarification is not possible.

- Hawthorn effect: When the experiment is used to research people, they often act in complex and unexpected ways that are beyond the parameters of experimental hypothesis. Experimental exactitude, which might require controlled conditions, tends to make people behave self-consciously or unnaturally.

- Self-rating: People want to be honest burn effect but some time they are not completely honest. Questionnaire without having to write the name can reduce the problem if the reason is to be afraid of the teacher. But this problem can happen if the reason is to pleased the teacher or trying not to make the teacher disappointed when students have some bad comments.

\section{Conclusion}

KWL strategy helps teachers activate learners prior knowledge called schema, concerning a topic or subject and it promotes research, active reading and inquisition since Schema theory can be a very useful theory which helps us understand how our brain processes information. Therefore, no one can deny that K-W-L strategy can promotes active learning. Active learning has become an important factor of education success and it involves other activities that learners do together in class apart from simply listening to lectures. Studies show students comprehend the topics better and also retain them for long if they can actively react to course material or lecture. That means K-W-L fosters active learning 
through enabling instructors to better assess their student learning levels during the course. In addition, KWL strategy also encourages academic success since learners learn actively using the K-W-L. It is likely that they will become even more connected to class and the topics or subject matter. They will therefore interact with class members and teacher, increasing their chances for academic success. Furthermore, this also enhances their probability of staying in school and graduating. The great relationship between faculty and students as an essential part of K-W-L fosters student retention in school. Last but not least, K-W-L strategy enhances learning as the prior knowledge has usually has a huge effect on learner performance. In other words, there is also a well-recognized relationship between learning comprehension and prior knowledge. Regardless of the ability of a student to read, high prior understanding of a certain subject area normally means better scores. Moreover, high prior understanding is also associated with enhanced learner interest in specific topics. In short, the use of K-W-L charts is particularly beneficial like a pre-reading strategy and it also serves like a test of what learners have studied during a certain study unit. $\mathrm{K}$ denotes what the learners know while $\mathrm{W}$ signifies what they desire learning, with the L standing for the knowledge gained by the learners as they research or read.

To sum up, following the proverb: "Seeing is believing", this research tried to prove the effect of the treatment. It also suggested a way to control a reading class, to create an interesting and exciting atmosphere. Hopefully, this research will be one way of motivating teachers to overcome the difficulties when teaching reading, and provide students opportunity to practice and improve their reading skill. Moreover, the treatment will be one of the ways to improve students' all basic skills in learning a language (reading, speaking, listening and writing); not only in English but also in all the languages they have opportunity to study, including their mother tongue to be successful in communication, especially in the process of globalization.

\section{References}

[1] Achersold and Field. From reader to reading teacher. CUP, 1997.

[2] Anthony, Pearson, \& Raphael'. Teaching Reading to English Language Learners: A Reflective Guide. Corwin Press, 1993.

[3] Barker, George C. Growing up in a Bilingual community. The Kiva 17. 17-32, 1951.

[4] Bateman W. G. A child's progress in speech, with detailed vocabularies. Journal of Educational Psychology 5.307-20, 1914.

[5] Dale T. Griffee \& Nunan D. Classroom Teachers and Classroom research. Japan Association for Language Teaching, Tokyo, 1997.

[6] Frank S Erafini. Classroom Reading Assessment. Heinemann Portsmouth, NH, 2000.

[7] Fromkin V, Roadman, Collins \& Blairs. An Introduction to Language. Second Australian Edition, 1990.
[8] Fromkin V, Roadman R, Hyams N. An Introduction to Language. Seventh American Edition, 2003.

[9] Fromkin V, Roadman R, Hyams N. An Introduction to Language. Nineth American Edition: Wadsworth Cengage learning, Canada, 2011.

[10] Griffee D. T. \& Nunan D, Classroom Teachers and Classroom research. Tokyo,Japan: The Japan Association for Language Teaching, 1997.

[11] Hughes A.. Testing for Language Teachers. CUP, 2002.

[12] Jacobs G. M,. \& Renandya W. A. \& Davis C. Successful strategies for Extensive Reading. SEAMEO Regional Center of Singapor, 1999.

[13] Lee S. McKay. The Reflective Teacher: A Guide to Classroom research. SEAMEO Regional Center of Singapor, 2007.

[14] Lewis M., Renandya W. A. \& Richards J. C. Giving feedback in language class. SEAMEO Regional Center of Singapor, 2002.

[15] Namara T. Mc. Language Testing. OUP Oxford, 2000.

[16] Nguyễn Thiện Giáp, Các phuoong pháp nghiên cưu ngôn ngũ. Nxb Giáo dục, 2009.

[17] Hadley G. Action Research in Action: Singapore: SEAMEO Regional Language Center, 2003.

[18] Kent Bach \& Robert Hamish M. Linguistic Communication and Speech Acts. Mltpress, 1979.

[19] Phạm Ngọc, Phạm Đức Dương, Tiếp xúc Ngôn ngũ ở Đông Nam Á. Viện Đông Nam Á, Hà Nội, 1983.

[20] Richard C. Anderson \& James W. Pichert. Recall of previously unrecallable information - Following a shift in perspective. University of Illinois at Urbana-Champaign, 1977.

[21] Richards J. C, \& Farrell T. S. C., Proffessional Development for Language teacher. Cambridge language Education.

[22] Richards J. C, \&, Renandya W. A. Methodology in language teaching. CUP, 2002.

[23] SEAMEO Regional Language Center, Research Methodology. Singapore: SEAMEO Regional Language Center, 2003.

[24] Seameo Regional language Center - Singapore, Language Acquisition. Social \& Psychological Dimension: SEAMEO, 2003.

[25] Bùi Khánh Thế, Lý thuyết tiếp xúc ngôn ngũ và vấn đề tiếp xúc ngôn ngũ ở Việt Nam. Cơ sở Đào tạo Sau đại học - Viện Khoa học Xã hội tại TP. Hồ Chí Minh, 1997.

[26] Uriel Weinreich, Language in contact: Findings and problems. Newyork, 1953.

[27] Weissberg R. \& Buker S.. Writing up research. Englewood Cliffs, NJ: Prentice Hall Regents, 1990.

[28] http://dosfan.lib.uic.edu/usia/E-USIA/forum/vols/vol35/no3/p 24.htm

[29] http://dosfan.lib.uic.edu/usia/E-USIA/forum/vols/vol37/no2/p 24.htm 